ACTA UNIVERSITATIS LODZIENSIS

FOLIA LITTERARIA POLONICA 1(47) 2018

http://dx.doi.org/10.18778/1505-9057.47.04

Kazimierz Adamczyk ${ }^{*}$

\title{
Raport i lament - zapiski z Auschwitz Załmena Gradowskiego
}

\begin{abstract}
Pamiętnik Z. Gradowskiego posiada wielką literacką wartość; został on napisany jakby z myślą o przyszłym wydawcy, który rękopis wydobyty z ziemi wyniesie na światło dnia i udostępni czytelnikom. Zaczynam od tej kwestii, bardzo ważnej albowiem siła tego dokumentu zasadza się nie tylko na prawdziwości relacji, lecz również na SPOSOBIE relacjonowania...!!
\end{abstract}

Autorem powyższych słów jest Stanisław Wygodzki, poeta, były więzień Auschwitz. Autor przejmującego tomu wierszy Pamiętnik mitości stracił w transporcie do Brzezinki żonę i córkę. Jego ocenę relacji sporządzonej przez Załmena Gradowskiego, zatytułowaną $W$ sercu piekta (In hare fun gihenomon) - wydaną w Izraelu nakładem Chaima Wolnermana - cytuję za artykułem, który ukazał się w izraelskich „Nowinach-Kurierze” w 1977 roku . Jest on polskojęzyczną wersją tekstu pisanego w jidysz, zamieszczonego w przywołanej wyżej publikacji. Obie wersje oprócz imienia pisarza (Jeheszwa i Stanisław) różnią się w niewielkim stopniu. W obu Wygodzki odwołuje się do własnych doświadczeń:

Przez rok cały obserwowałem teren krematoriów I i II, mianowicie z Krankenbau. Otóż z tego obozu, poprzez druty, z odległości niewielu metrów, można było widzieć ludzi pędzonych ku terenowi krematoriów; poprzez żywopłot mogłem widzieć grupy idących, mogłem zaobserwować ss-manów zaglądających do komór po wrzuceniu trucizny, lecz tego, co się działo na podwórzu, przed wejściem do bunkra, w przejściu z bunkrów do komór, w pobliżu pieców, tego nikt nie mógł widzieć. To wszystko widział Gradowski...2

* Dr hab., adiunkt; Uniwersytet Jagielloński, Wydział Polonistyki, Katedra Historii Literatury Polskiej XX wieku; ul. Gołębia 16-18, 30-007 Kraków; kazimierz.adamczyk@uj.edu.pl.

${ }^{1}$ S. Wygodzki, W sercu piekta, „Nowiny-Kurier” 1977, nr 157, s. 8.

${ }^{2}$ Tamże. 
Przytoczone w charakterze motta i cytatu słowa żydowskiego emigranta z Polski wprowadzają nas w centrum dyskusji dotyczących możliwości reprezentacji doświadczenia Holokaustu. Ważne jest, iż mówi do nas Żyd ocalony z Shoah. Zastanawia się on nad możliwością zrozumienia mechanizmu Zagłady przez więźnia obozu, nad istotą świadectwa Gradowskiego i jego adresem. Pyta o rodzaj języka, w jakim zostało napisane, i o miejsce twórczość artystycznej w zetknięciu z horrorem ludobójstwa.

Przedmiotem namysłu w niniejszym artykule są cztery publikacje notatek Gradowskiego: [List] i [Dziennik], które ukazały się w numerze specjalnym „Zeszytów Oświęcimskich”’, Wolny człowieku wiedz, że to jest ogień z piekła... z biuletynu „Pro memoria" ${ }^{\text {"4 }}$ oraz fragment Noc księżycowa zawarty w książce Piotra M.A. Cywińskiego 5 .

Załmen Gradowski urodził w Suwałkach w roku 1908 lub 1909, był Żydem religijnym, po zawarciu małżeństwa osiedlił się w Łunie - miejscowości leżącej w pobliżu Grodna. Przed wojną podjął próby literackie, ale nie widział możliwości odniesienia $w$ tej dziedzinie sukcesu ${ }^{6}$. Zaangażowany był w ruch syjonistyczny i zamierzał w roku 1940 wyjechać z Polski do Palestyny. Wojna nie pozwoliła mu na urzeczywistnienie tego planu. W listopadzie 1942 Gradowskiego wraz $\mathrm{z}$ rodziną przesiedlono do obozu przejściowego w Kiełbasinie. W grudniu przetransportowano ich do KL Auschwitz, gdzie 8 grudnia, podczas rozładowywania pociągu i w wyniku selekcji, utracił matkę, żonę, dwie siostry, teścia i szwagra zginęli w komorach gazowych. Po pewnym czasie Niemcy zmusili go, ze względu na silną budowę ciała, do pracy w Sonderkommando. Tu przydzielony został do palenia zwłok w krematorium?7. Szlama Dragon, który w marcu 1945 roku wskazał miejsce zakopania rękopisu Gradowskiego, wspomina, iż jego autor prowadził ewidencje transportów, listę ludzi zagazowanych, a w swych notatkach „całościowo opisał proces zagłady”. Twierdzi też, iż współwięźniowie cenili jego

${ }^{3}$ Z. Gradowski, [List], [Dziennik], przekł. B. Mark, popr. i uzup. R. Pytel, „Zeszyty Oświęcimskie" 1972, nr specjalny (II): Wśród koszmarnej zbrodni. Rękopisy członków Sonderkommando, s. 131-162. Korzystam z 2. wydania rozszerzonego z roku 1972 (Wydawnictwo Państwowego Muzeum w Oświęcimiu, s. 131-133 i 133-162).

${ }^{4}$ Z. Gradowski, Wolny czlowieku wiedz, że to jest ogień z piekła..., „Pro memoria” 2006, nr 25, s. $35-44$.

${ }^{5}$ Z. Gradowski, Noc księżycowa, przekł. E. Golińska, w: P.M.A. Cywiński, Zagłada w pamięci więźniów Sonderkommando, Państwowe Muzeum Auschwitz-Birkenau, Oświęcim 2015, s. $69-82$.

${ }^{6}$ Informacje biograficzne podaję za prof. Bernardem Markiem. Pisząc o uzdolnieniach literackich Gradowskiego, powołuje on się na powojenne świadectwo dr. Dawida Sfarda. Zob. B. Mark, O rękopisie Zatmena Gradowskiego, w: Wśród koszmarnej zbrodni..., s. 128-130.

${ }^{7}$ Wywiad z Abrahamem i Szlamą Dragonami, w: G. Greif, ,....płakaliśmy bez łez...”. Relacje byłych więźniów żydowskiego Sonderkommando z Auschwitz, tłum. J. Kapłon, konsultacja nauk. F. Piper, P. Setkiewicz, Żydowski Instytut Historyczny, Państwowe Muzeum Auschwitz-Birkenau, Warszawa-Oświęcim 2001, s. 152. 
dokumentacyjną pracę, a on sam, będąc sztubowym, załatwił mu łóżko przy oknie, by „miał więcej światła do pisania” ${ }^{8}$. Gradowski był jednym z organizatorów buntu Sonderkommando, do którego doszło 7 października 1944 roku. W jego wyniku zniszczone zostało IV krematorium, SS-mani zabili około 450 więźniów9 ${ }^{9}$. Ciało powieszonego Gradowskiego ze śladami okrutnych tortur, zmiażdżoną czaszką, widział Yaakov Freimark 8 października ${ }^{10}$.

Zapiski Gradowskiego są świadectwem trojakiego rodzaju. Po pierwsze, i to jest ich prymarna funkcja, dokumentują widziany oczyma więźnia i członka Sonderkommando proces Zagłady. Zawierają opis transportu Żydów do obozu i zapis ludobójstwa dokonujący się w komorach gazowych. Auschwitz-Birkenau jest w jego relacji przestrzenią śmierci, zwłok i ludzkich prochów. To perfekcyjnie działająca fabryka trupów, zarządzana poprzez ekstremalny terror. Skuteczność nazistów opiera się na wszechobecnym zabijaniu i jednoczesnym łudzeniu ofiar nadzieją przeżycia. Członkowie Sonderkommando uczestniczą w tym dziele unicestwienia ponad miliona osób. I tutaj jego zapiski są świadectwem innego jeszcze rodzaju. Jak wskazywał Wygodzki, po raz pierwszy otrzymaliśmy portret psychologiczny więźnia Sonderkommando. Jest on daleko różny od wizerunków kreślonych przez więźniów Auschwitz z innych komand. Wiesław Kielar opisuje ich jako ludzi pozbawionych moralności: „Sonderowcy to już nie ludzie. Odarci ze wszelkich ludzkich uczuć, które spłonęły równocześnie z ich najdroższymi i najbliższymi sercu istotami - zostali znieczuleni na ludzką niedolę" ${ }^{\prime 1}$. Przypomnijmy, iż Primo Levi wskazywał ich jako przypadek graniczny szarej strefy, nie mniej odmawiał potępienia członków tego komanda: „Dlatego chciałbym, żeby dzieje «kruków z krematorium» rozpatrywano rzetelnie, żeby im okazywano miłosierdzie, ale ich nie osądzano" 2 . Gradowski nie był zapewne typowym sonderkommandowcem, to człowiek głęboko religijny, wykształcony humanista. Jego relacja przepełniona jest empatią do ofiar i współwięźniów. Owa głęboka empatia uruchamia słowa patetyczne i pełne emocji. Tu chyba, oprócz być może naturalnych dyspozycji Gradowskiego - jak rzecz ujmuje Nathan Cohen ${ }^{13}$ - tkwi źródło stylistycznej wartości naddanej w stosunku do czysto sprawozdawczego języ$\mathrm{ka}$, jakiego byśmy oczekiwali w relacji z krematorium. Istotne są też warunki, w jakich żyło Sonderkommando, dawały one możliwość prowadzenia zapisków i pracy nad ich kształtem. SS-mani nie wchodzili do pomieszczeń, w których

${ }^{8}$ Tamże, s. $152-153$.

${ }^{9}$ D. Czech, Kalendarz wydarzeń w KL Auschwitz, Wydawnictwo Państwowego Muzeum w Oświęcimiu-Brzezince, Oświęcim 1992, s. 778-779.

${ }^{10}$ N. Cohen, „Diaries” of the Sonderkommando, w: Anatomy of the Auschwitz Death Camp, red. Y. Gutman i M. Berenbaum, Indiana University Press, Bloomington 1998, s. 523.

${ }^{11}$ Wiesław Kielar, Anus mundi, przedm. M. Kieta, Atut, Wrocław 2004, s. 245.

${ }^{12}$ P. Levi, Pogrążeni i ocaleni, przekł. S. Kasprzysiak, Wydawnictwo Literackie, Kraków 2007, s. 69.

${ }^{13}$ N. Cohen, dz. cyt., s. 525. 
mieszkali jego członkowie, więźniowie nie doświadczali też głodu, nie uczestniczyli w apelach pełniących rolę selekcji słabszych więźniów. Żyli natomiast w absolutnej pewności swojej śmierci w obozie.

Nie mamy pewności, iż wszystkie fragmenty notatek Gradowskiego ocalały i zostały znalezione. Stąd trudno jest patrzeć na jego zapisy jak na dzieło o przemyślanej kompozycji, zwłaszcza, iż fragmenty były niezależnie publikowane w Polsce przez Państwowe Muzeum w Oświęcimiu i Chaima Wolnermana w Izraelu. Przyjmując chronologiczną dominantę zapisu zdarzeń, musimy przyjąć, iż najwcześniej powstała część notatek opublikowanych w „Zeszytach Oświęcimskich”.

I.

W odnalezionych w Auschwitz w dniu 5 marca 1945 roku kartach ukryty był list adresowany do przyszłego ich znalazcy:

„Drogi znalazco, szukaj wszędzie, na każdej piędzi ziemi. Pod nią zakopano dziesiątki dokumentów, moich i innych osób, które rzucą światło, na wszystko, co się tu działo. Zakopano tu także mnóstwo zębów"14.

Przeczytamy w nim także informację, iż notatki były wcześniej ukryte w popiołach ludzkich, ale zostały wykopane i przeniesione w inne miejsce, gdyż Niemcy rozpoczęli akcję zacierania śladów zbrodni i wysypywania ludzkich popiołów do Wisły. Pozostał w nich zapach ,nie zawsze całkowicie spalonych kości i kawałków mięsa"15. Ten zapach, jakim przesiąknięte są zapisane kartki, to jeszcze jeden materialny dowód zbrodni ludobójstwa. W liście wyrażone jest przekonanie, iż mimo dobrych wiadomości z frontu, jego autor nie doczeka czasu wyzwolenia obozu. Wyraża też nadzieję na wybuch buntu w obozie: „Ten dzień jest bliski, może się to stać dzisiaj albo jutro. Piszę te słowa w momencie największego niebezpieczeństwa i podniecenia" ${ }^{16}$. Czas powstawania zapisu pokrywa się z czasem likwidacji w Auschwitz Żydów czeskich i słowackich, o czym w [Liście] znajdziemy informację. Autor świadomy jest etycznych kontrowersji dotyczących postawy więźniów, którzy pracują w Sonderkommando. W ostatnim zdaniu wyraża nadzieję, iż historia oceni ich sprawiedliwie: „Niechaj przyszłość wyda na nas wyrok na podstawie moich notatek, i niechaj świat ujrzy w nich bodaj kroplę, minimum tego tragicznego świata, w którym żyliśmy"17.

\footnotetext{
${ }^{14}$ Z. Gradowski, [List], s. 132.

15 Tamże.

16 Tamże, s. 133.

17 Tamże.
} 
[List] jest zatem instrukcją dla znalazcy notatek, przekazuje podstawowe informacje o okolicznościach powstania zapisków, wskazuje na zamiar udokumentowania niemieckich zbrodni, mówi o woli buntu w obozie i przekonaniu o nieuchronnej śmierci, które podkreśla apel o przyszłe uczciwe osądzenie członków Sonderkommanda. To drugi z celów prowadzenia notatnika. Ma on dostarczyć materiału do wydania sprawiedliwego wyroku. Być może w tym zdaniu Primo Levi, inaczej niż Stanisław Wygodzki, dostrzegł chęć usprawiedliwiania się i nie uczynił wykopanych na terenie krematorium świadectw przedmiotem głębszego namysłu.

\section{II.}

Druga, dłuższa część świadectwa Gradowskiego, odnaleziona 5 marca 1945 roku, pisana w jest formie pamiętnika. W „Zeszytach Oświęcimskich” nadano jej tytuł Dziennik. Wymiennie tymi formami posługuje się Stanisław Wygodzki. W recenzji w „Nowinach-Kurierze” pisze o pamiętniku Gradowskiego, w książce $W$ sercu piekła - jeśli nie ma tu ingerencji tłumacza - posługuje się gatunkową nazwą 'dziennik'. Ta terminologiczna niekonsekwencja dowodzi, że w interpretacji świadectw Holokaustu posługiwanie się klasyfikacjami gatunkowymi ma ograniczoną użyteczność.

Tekst rozpoczyna się dedykacją dla spalonych żywcem w Auschwitz-Birkenau członków najbliższej rodziny oraz notą mówiącą o historycznej wartości zapisu. Relację kończy wyjaśnienie:

Pisałem to dziesięć miesięcy przedtem. Przybyłem z Łuny, okręg Grodno, z obozu $\mathrm{w}$ Kiełbasinie. Zakopałem to $\mathrm{w}$ dole pod popiołem, uważałem to za najpewniejsze miejsce, gdzie na pewno na terenie krematorium będą kopać. Lecz ostatnio $[\ldots]^{18}$.

Wspomnienie obejmuje zapis transportu z obozu przejściowego w Kiełbasinie do KL Auschwitz-Birkenau oraz pierwsze dni uwięzienia w największym z obozów zagłady, zakończone wcieleniem autora do Sonderkommanda. Można wskazać trzy dyrektywy organizujące ten fragment świadectwa Gradowskiego. Po pierwsze, jest nim konwencja zwrotu do wyimaginowanego adresata-przyjaciela - to powtarzający się chwyt retoryczny, którego celem jest poruszenie i wywołanie emocjonalnego zaangażowania $\mathrm{w}$ przyszłym czytelniku ${ }^{19}$. Po drugie, zwraca

${ }^{18}$ Z. Gradowski, [Dziennik], s. 162.

${ }^{19} \mathrm{~W}$ tym miejscu warto zwrócić uwagę na inny tekst, także odnaleziony w pobliżu krematorium. Nieznany żydowski autor opisuje w nim, w formie listu do przyjaciela, warunki życia w getcie łódzkim. Jego relację (odczytaną po żmudnych konserwatorskich zabiegach) opublikowało 
uwagę strategia narracyjna, w której opowiadający posługuje się retardacją, a sam sytuuje się w sytuacji podmiotu znającego ostateczną prawdę o losie transportu. W ramach tej dyrektywy kompozycyjnej dzieje wiezionych do Auschwitz są wypełnieniem fatalnego przeznaczenia. Trzecia dyrektywa jest dyrektywą dokumentu, którego celem jest przekazanie świadectwa męczeństwa i śmierci w komorach gazowych tysięcy Żydów z białostocczyzny. Autor wspomnienia posługuje się różnorodnym usytuowaniem narratora, patrzy na uwięzionych w wagonach z perspektywy olimpijskiej, właściwej dziewiętnastowiecznej narracji realistycznej, następnie przyjmuje ich punkt widzenia, jest narratorem współuczestniczącym, wszak był więźniem tego transportu. Kreuje lub odtwarza - tego nie wiemy i kryterium autentyzmu nie jest tu istotne - myśli wiezionych do Auschwitz, niepewność, zagubienie, lęk, nadzieję, uczucia rodzinnej miłości i właściwe mężczyznom przekonanie o ich odpowiedzialności za los kobiet i dzieci. Zasadą kompozycyjną tekstu staje się dialektyka rozpaczy i złudzenia przynoszącego uspokojenie. Można widzieć w sposobie przedstawiania uwięzionych w pociągu podobieństwo do techniki filmowej, pokazany czytelnikowi zostaje plan ogólny i zbliżenia kamery na poszczególnych bohaterów. Wrażenie to potęgują pojawiające się wezwania: ,zobacz”, „popatrz”, „widzisz”. Jednocześnie przedstawiony świat jest opisywany w kategoriach antyświata, w którym duchowość człowieka zostaje unieważniona poprzez głód, pragnienie i bicie. W końcu znajdą się w obozie śmierci, ci, którzy przeżyli selekcję, zostaną pozbawieni własnego ,,ja”, odarci z każdej rzeczy wiążącej ich z dawnym światem. Na ,wyspie śmierci” nie rozumieją języka współwięźniów, którzy wydają się im postaciami nierzeczywistymi. To świat, w którym ,rozdzielone zostaje to, co jest nierozerwalne”, w którym „,nierealne stało się rzeczywistością, faktem" ${ }^{20}$. Końcowe fragmenty zdominowane są przez powtarzający się motyw lęku o losy rodziny. W końcu słyszą: „Oni są już w niebie” i ,Wasze rodziny puszczono już z dymem" ${ }^{21}$.

Wydawnictwo Łódzkie w roku 1965 w książce Szukajcie w popiołach. Papiery znalezione w Oświęcimiu w tłumaczeniu Szymona Datnera z jidysz i hebrajskiego, w opracowaniu Janusza Gumkowskiego oraz Adama Rutkowskiego. Adresatem listu jest niezidentyfikowany Willy. Wydawcy twierdzą, iż postać ta jest zmyślona. Z kolei autorzy publikacji włoskiej Diario dal Ghetto di Łódź (Roma 1989) przychylają się do opinii, iż adresat listów z łódzkiego getta był osobą rzeczywistą. Kontrowersje te opisuje Anna Szwarc Zając w artykule Willy, przyjaciel prawdziwy czy wymyślony? Rozważania nad polskim i włoskim tłumaczeniem ksiażki „,Szukajcie w popiołach” („Zagłada Żydów. Studia i Materiały” t. 8 [2012], s. 403-418). Autorka zwraca uwagę na styl odbioru tekstu przez współczesnego czytelnika. Willi obecny w listach, prawdziwy czy zmyślony, wymusza mechanizm utożsamienia się czytającego z odbiorcą korespondencji, co według niej uruchamia wyobraźnię i decyduje o literackim naddatku odnalezionego dokumentu. Czy podobny mechanizm działa w wypadku notatek Gradowskiego adresowanych do przyjaciela? Raczej nie, można natomiast mówić o pewnym wezwaniu do współświadczenia poprzez akt lektury.

${ }^{20}$ Z. Gradowski, [Dziennik], s. 149.

${ }^{21}$ Tamże, s. 154. 
Narrator wspomnienia, z racji swojej wiedzy o losach transportu i losach swojej najbliższej rodziny, posługuje się zmiennym dystansem wobec przywoływanych w zapisie skazańców. W relacji dominuje jednak zaimek „my” obejmujący narratora i resztę pasażerów, a czasem naród żydowski. To „my” przeciwstawione jest Niemcom. Oprawcy opisywani są jako „barbarzyńcy” „podli bandyci”, „okrutne bestie”, „podłe kreatury”, dla których Żydzi są najważniejszym wrogiem $^{22}$. Już na początku tekstu powiedziane zostaje, iż Żydzi znajdują się w sieci szatana. Narrator opisuje też zbiorową modlitwę uwięzionych, prośbę do Boga o opiekę: „Melodia błaga: prowadź nas dalej po drodze życia jak dotąd. Pozwól dotrzeć do celu naszej podróży i niech wszystko skończy się jak dotąd na strachu"23.

[Dziennik] Gradowskiego opublikowany w „Zeszytach Oświęcimskich” wykracza poza dokumentalną relację o faktach, jest tekstem o charakterze literackim. Wartość naddana wobec hipotetycznie wyobrażonego tekstu czysto sprawozdawczego widoczna jest we wszystkich niemal warstwach relacji: kompozycji, sposobie prowadzenia narracji i stylistyce. Nie oznacza to bynajmniej, iż zagubiony został podstawowy jej cel - informacyjny. Trasa pociągu została dokładnie opisana, wiadomości o zagładzie Żydów w Treblince i Auschwitz przekazane, zwrócona też została uwaga na różnorodność ludzkich postaw wobec męczeństwa Żydów. Zwraca uwagę sadyzm Niemców i gest podrzynania gardła pokazywany przez dwie chrześcijanki na widok transportu. W całym tym fragmencie [Dziennika] Gradowskiego dominuje konwencja faktograficzna wykorzystująca narracyjne strategie prozy realistycznej.

\section{III.}

Z innymi jeszcze predyspozycjami artystycznymi Gradowskiego spotykamy się podczas lektury fragmentów wspomnień wydanych w Izraelu nakładem Chaima Wolnermana. Dotychczas ukazały się dwa fragmenty przełożone na język polski: Noc księżycowa i Wolny człowieku wiedz, że to jest ogień z piekła... Ten ostatni tytuł jest dziełem redakcji pisma „Pro memoria”. W języku polskim nie opublikowano jeszcze zapisków, w których opisany jest dramatyczny epizod z dziejów Sonderkommanda, kiedy to w sierpniu 1944 roku Niemcy zgładzili w głównym obozie w Auschwitz dwustu jego członków ${ }^{24}$. Noc księżycowa jest

22 Tamże, s. 145.

${ }^{23}$ Tamże, s. 139.

${ }^{24} \mathrm{~W}$ języku angielskim tytuł tego fragmentu brzmi The Parting. W cytowanym wcześniej artykule Cohen pisze, iż Gradowski miał nadzieję na wzniecenie buntu przez świadomych swego losu członków Sonderkommando. Wtedy jednak do buntu nie doszło. 
zapewne tą częścią zapisów Gradowskiego, która kazała pytać Wygodzkiemu o miejsce sztuki w tak ekstremalnych doświadczeniach. Artystowska postawa, cyzelowanie literackiego tekstu - sugeruje poeta - były swego rodzaju azylem, obroną przed dehumanizacją i uprzedmiotowieniem ${ }^{25}$. Oba fragmenty łączy symbolika księżyca i skarga wniesiona do Boga. Przy czym Noc księżycowa nie jest wpisana w chronologię wydarzeń, mogłaby stanowić odrębny utwór, którym zapiski Gradowskiego mogą się zarówno rozpoczynać, jak i kończyć. Ze względu na możliwy brak innych fragmentów raczej nie możemy zrekonstruować zamiarów Gradowskiego.

Fragment Wolny czlowieku wiedz... opisuje zagazowanie pięciu tysięcy czeskich rodzin żydowskich, które po przewiezieniu z Teresina żyły całymi rodzinami w barakach Brzezinki przez prawie sześć miesięcy. Gradowski tę część notatek rozpoczyna adresem do „Drogiego czytelnika”, w którym wyjawia cel ich prowadzenia. Powtarzające się zwroty do „przyszłego znalazcy”, „,zytelnika”, którymi opatruje każdą część swoich notatek, są wyrazem lęku o los powierzanych ziemi zapisów i ustanawiają podstawową ich funkcję, czyli zaświadczenia o zbrodniach przekraczających ludzką wyobraźnię.

Drogi czytelniku, w napisanych wierszach znajdziesz wyraz cierpień i nieszczęść, jakie my, najnieszczęśliwsze dzieci całego świata, przeżyliśmy w czasie swego życia w ziemskim piekle, które nazywa się Brzezinka-Oświęcim. Sądzę, że świat już dobrze zna tę nazwę, lecz nikt na pewno nie uwierzy, co się tu naprawdę dzieje. Inni myślą i sądzą, że jeśli gdzieś przez radio podaje się o barbarzyństwie, okrucieństwie, brutalności z jaką traktuje się tutaj człowieka, to jest to tylko Gruelpropaganda - a ja ci chcę teraz udowodnić, że wszystko, co słyszałeś, a także to, co ja tu piszę, to tylko minimum tego, co się tutaj rzeczywiście stało. Tutaj jest miejsce, które przez bandycką władzę zostało przeznaczone na kąt zagłady specjalnie dla naszego narodu; częściowo także dla innych narodów [...]. Celem mojego pisania jest, ażeby chociaż minimum rzeczywistości dotarło do świata i niech świat dokona za to wszystko ze$\mathrm{msty}^{26}$.

Zobowiązanie zostaje w tym fragmencie wypełnione. Gradowski opisuje metodykę zbrodni, trzydniowe do niej przygotowania, zamknięcie wszystkich więźniów w barakach, rozdzielnie mężczyzn i kobiet, mistyfikację pozwalającą łudzić się kierowanym do eksterminacji w komorach gazowych, że czeka ich inny los. Opisuje, jak członkowie Sonderkommanda pomagają zaprowadzić kobiety i mężczyzn do łaźni. Odwołuje się do zmyślenia, kiedy opisuje historie par małżeńskich pędzonych do komór, a także odtwarza myśli zatrwożonych Żydów

${ }^{25}$ S. Wygodzki, W sercu piekła..., s. 8.

${ }^{26}$ Z. Gradowski, Wolny człowieku wiedz..., s. 35. 
i Żydówek. Ale ta fikcja, pozostając na usługach świadectwa, oddaje, jak w reportażu literackim, prawdę rozpaczy, lęku, przerażenia, a także prawdę miłości. To z tego fragmentu pochodzą słowa, które zostały wybrane w Izraelu na tytuł książki $W$ sercu piekła. Oto obraz, jaki ukazuje się po otwarciu drzwi komory gazowej:

Leżą tam, mimo że nie upadli, spleceni jeden z drugim, splątani w kłąb, jakby jeszcze przed śmiercią sam diabeł prowadził z nimi jakąś szatańską grę i poustawiał ich $\mathrm{w}$ takiej pozycji. Tu leży ciało na innym ciele, tam jeden obejmuje drugiego i siedzą przy ścianie. Tu wystaje tylko część pleców, podczas gdy głowa i nogi tkwią między innym zwłokami, tam widać tylko rękę, noga sterczy w powietrzu, całe ciało stapia się z morzem nagości. Na powierzchni świata nagości widzisz tylko część ciał zmarłych ludzi. W tym wielkim nagim morzu pływa teraz mnóstwo głów. Trzymają się mocno ponad nagimi falami. Wygląda to tak, jakby pływali w wielkim głębokim morzu, a widać tylko ich głowy. Czarne, blond i brązowe głowy są jedynymi częściami ciała, które wyłamują się z panującej wszędzie dookoła nagości²7.

Wcześniej Gradowski opisuje zachowania tłumu Żydów w łaźni, przedsionku komory gazowej. Obok opisu ekstremalnego przerażenia ofiar, zadawanego im cierpienia i bólu spowodowanego biciem, znajdujemy w jego relacji ekstatyczną pochwałę życia. Każda z ofiar jest dla niego odrębnym światem. To założenie judaizmu wypowiedziane kilkukrotnie, wzmocnione zostaje poprzez wspomniane elementy fikcji, służące zindywidualizowaniu portretów osób prowadzonych na śmierć. Cała akcja likwidacji czeskiego rodzinnego obozu w Brzezince zostanie spuentowana stwierdzeniem o zamordowaniu tego dnia pięciu tysięcy światów. Przywołany powyżej opis przedstawia skrajne uprzedmiotowienie ludzkiego ciała, masę nagich trupów. Metafora morza ciał wydawać się może jakimś ekscesem stylu, odwołuje się jednak do wyobraźni odbiorcy, pokazując z jednej strony efekt produkcji komór gazowych, jednolitą, pozbawioną indywidualnych cech, masę nagich ciał, ale z drugiej, Gradowski, zwracając uwagę na różny kolor włosów pomordowanych, nikły wyróżnik ich tożsamości, przeciwstawia się unifikacyjnej sile śmierci. Ten posługujący się metaforyką opis poprzedzony jest doznaniem absolutnej ciszy, w której ,słychać ledwie uchwytny szum, to z różnych otworów martwych ciał wycieka płyn. To jedyne, co tutaj się porusza w tym wielkim, martwym świecie"28.

Obraz, jaki ukazuje się oczom Gradowskiego i jego przyszłego czytelnika, to jeden $\mathrm{z}$ trzech, jakie przedstawia dla udokumentowania przebiegu ludobójstwa dokonującego się w komorach gazowych Auschwitz. Kolejne dwa, użyte w tym

\footnotetext{
27 Tamże, s. 43.

${ }^{28}$ Tamże.
} 
celu przez autora Czasu eksterminacji, również pochodzą z relacji Gradowskiego $^{29}$. Przedstawiają one opróżnianie komór gazowych ze zwłok oraz przebieg procesu kremacji: „Najdłużej pali się głowa. Z oczu świecą niebieskie płomyki - to wypalają się oczy z głębokim jądrem, a w ustach pali się jeszcze język. Cała procedura trwa 20 minut - i ciało - świat zamieniło się w popiół" ${ }^{\prime 30}$.

Dokumentalna wartość tej części notatek Gradowskiego - opisu likwidacji pięciu tysięcy Żydów czeskich nie budzi żadnych wątpliwości. Tekst pisany w Auschwitz powstał rzeczywiście w ,sercu piekła”. Zwróćmy uwagę, iż Gideon Greif autor głośnych wywiadów z ocalałymi członkami Sonderkommanda, przeprowadzonymi czterdzieści lat po wojnie, cytuje zamiast komentarza historycznego całe strony z zapisów Gradowskiego ${ }^{31}$. Trudno o bardziej jednoznaczne potwierdzenie istotności tego świadectwa. Jest oczywiste, że o wiarygodności relacji - co wspomniałem już w tym artykule - decydują okoliczności jej powstania, zawarte w niej informacje oraz osoba świadka. Omawiana tu część notatek Gradowskiego, Wolny człowieku wiedz, że to jest ogień z piekła..., wzbogaca portret duchowy ich autora poprzez treść, język i sposób zredagowania ${ }^{32}$.

Podkreślić należy głęboką identyfikację Gradowskiego z żydowskim narodem. Pracując w krematoriach przy komorach gazowych, wie, iż celem Niemców jest unicestwienie Żydów z całego europejskiego kontynentu:

tu jest miejsce, które specjalnie zbudowano i przeznaczono na zgładzenie naszego narodu przez zagazowanie, zastrzelenie, zarzynanie albo przez ogień i męki, wysysając z nich szpik i krew przy ciężkiej pracy, której towarzyszy bicie, aż padają zemdleni w głębokiej glinie; ich wyschnięte ciało, zastygłe na zawsze, pozostaje na miejscu $^{33}$.

Szli jak żałobnicy z nisko pochylonymi w smutku głowami. Wiał od nich żal i przygnębienie, które udzieliło się także wszystkim Żydom w obozie. Bo ich droga, którą maszerują, to droga do krematorium, do piekła żydowskiego narodu ${ }^{34}$.

Identyfikacja wyrażona zostaje także wielokrotnie poprzez nazywanie ofiar braćmi i siostrami. Widok maltretowanych kobiet, przerażonych i idących na śmierć ze swoimi dziećmi wywołuje u kronikarza szczególne wzburzenie i eksplozję nienawiści skierowaną przeciwko Niemcom, którzy przeklinani są niczym

${ }^{29}$ Zob. S. Friedländer, Czas eksterminacji. Nazistowskie Niemcy i Żydzi 1939-1945, przekł. S. Kupisz, A.M. Nowak, K. Masłowski, Prószyński Media, Warszawa 2010, s. 652-653.

${ }^{30}$ Z. Gradowski, Wolny człowieku..., s. 43.

${ }^{31}$ G. Greif, ,...plakaliśmy bez łez...”, s. 42-87.

32 Mam świadomość, iż moje uwagi dotyczące językowego ukształtowania notatek Gradowskiego obarczone są ryzykiem interpretacji przekładu.

${ }^{33}$ Z. Gradowski, Wolny człowieku..., s. 36.

${ }^{34}$ Tamże, s. 38. 
biblijny Haman. Dwukrotnie wyraża też pragnienie zemsty ${ }^{35}$ oraz nadziei na odpłatę, jaką Niemcy dostaną od wolnego świata. Obok demonizacji Niemców widoczny jest zabieg ich pomniejszenia, szyderczej ironii zwróconej przeciwko sile militarnej zmobilizowanej w tej akcji przeciwko bezbronnym żydowskim rodzinom. Istotnym rysem autoportretu Gradowskiego, widocznym w omawianym fragmencie, jest poczucie solidarności ze współwięźniami z Sonderkommanda. Relacja podkreśla dramatyzm ich przeżyć. Na planie gramatycznym owa empatia wyrażona zostaje poprzez zaimek „my”, obejmujący autora i współtowarzyszy z komanda śmierci:

Plan ułożono z wojskową punktualnością. My, najnieszczęśliwsze ofiary naszego narodu, zostaliśmy ustawieni na linii bojowej przeciw naszym własnym siostrom i braciom. Mamy być pierwszą linią, na którą rzucą się ofiary w obozie z całymi rodzinami... ${ }^{36}$

Przypomnijmy, iż jednym z deklarowanych celów prowadzenia notatek jest dostarczenie przesłanek do wydania przez świat powojenny sprawiedliwej oceny więźniów Sonderkommanda. Gradowski kilkakrotnie wyraża nadzieję, iż ofiary rzucą się na swoich oprawców, a sonderkommandowcy przyłączą się do buntu. Wielokrotnie wyraża rozczarowanie, iż nie dochodzi do takich wydarzeń, jednocześnie przedstawia mechanizm terroru, uniemożliwiający spontaniczne akcje prowadzonych na śmierć.

W omawianej części zapisek Gradowski w faktograficzną narrację wplata refleksje o charakterze metafizycznym. Opis męczeństwa Żydów wielokrotnie nazwany jest piekłem, a horror, jaki jest tu przedstawiony, każe przywoływać dzieło Dantego. W Auschwitz diabeł jest po stronie Niemców. Ich bóg okazuje się silniejszy, to jemu składana jest ofiara z narodu żydowskiego. W opisach pojawia się także nieczuła, zimna przyroda, ulega ona symbolicznemu podwojeniu:

A księżyce - niewątpliwie są dwa. Księżyc dla narodów, łagodna miłość, która rozdziela światu uśmiechy i słyszy śpiew szczęścia i radości. I księżyc dla naszego narodu. Okrutny brutalny, który stoi sobie spokojny, zastygły i słyszy jęki i krzyki serc milionów, które zmagają się z nadchodzącą dla nich śmiercią ${ }^{37}$.

W metaforycznym języku wyrażona zostaje radykalnie odmienna sytuacja Żydów, świadomość czekającej ten naród Zagłady. Symbolika księżyca jest tutaj wieloznaczna. W innym fragmencie Gradowski w księżycu upatruje świadka

${ }^{35}$ Warto zauważyć, że S. Wygodzki w przywołanym artykule podkreśla brak uczucia zemsty w zapiskach Gradowskiego.

${ }^{36}$ Z. Gradowski, Wolny człowieku..., s. 37.

${ }^{37}$ Tamże, s. 35. 
wydarzeń, nad którym nie mają władzy siły piekła: „Tylko nocy, niebu gwiaździstemu i świecącemu księżycowi diabeł nie może niestety zasłonić oczu. I tylko oni będą świadkami tego, co diabeł robi dzisiejszej nocy"38.

Likwidacja pięciu tysięcy czeskich żydowskich rodzin odbyła się w dniu radosnego żydowskiego święta Purim, przypominającego, iż ludzkimi losami nie rządzi przypadek, lecz Bóg, który w czasach biblijnych ocalił Żydów przed Hamanem. Gradowski wskazuje na celowe działanie Niemców, którzy dokonują mordu w czas święta i zamieniają Purim w Tisza B'Aw [pisownia oryginalna - K.A.] - dzień żałoby, w którym upamiętnia się zgodnie z żydowską tradycją zburzenie Pierwszej Świątyni Jerozolimskiej przez króla babilońskiego Nabuchodonozora oraz Drugiej Świątyni przez cesarza Tytusa. W świecie obozu i zagłady Żydzi pozbawieni zostają poczucia wiecznego wymiaru czasu.

IV.

Ostatni z opublikowanych dotychczas w języku polskim fragmentów zapisów Gradowskiego nosi tytuł Noc księżycowa. To tekst, który mógłby współtworzyć postulowane przez Primo Leviego zapisy nowej Biblii, byłby to jej fragment poetycki. Jest to wypowiedź o charakterze lirycznym, będąca lamentem nad losem narodu żydowskiego, a także pretensją adresowaną do Jahwe. Kompozycyjny kształt poematu wyznaczony jest przez dynamikę powtarzających się pytań: dlaczego?, czy widzisz?, co czujesz? - skierowanych do księżyca. David Roskies, zwracając uwagę na retorykę powtórzeń i obecność apostrof do przyrody jako cechę charakterystyczną zapisków, pisze o długu, jaki Gradowski spłaca polskiej tradycji romantycznej ${ }^{39}$. Wydaje się, że istotniejsze znaczenie ma tu gęsta sieć odwołań do żydowskiej tradycji folklorystycznej oraz tekstów biblijnych.

Uporczywe, wielokrotnie zadawane pytanie o przyczynę zagłady narodu żydowskiego buduje tragizm i patos wypowiedzi. Podmiot mówiący możemy identyfikować z konkretnym Załmenem Gradowskim, więźniem Sonderkommando. Przebywa on na skrawku ziemi, na którym zamordowano jego naród. Kreowana w poemacie przestrzeń przywołuje elementy krajobrazu śmierci Auschwitz-Birkenau. Pojawiają się komory gazowe i kominy krematoriów, a nawet sylwetki dwóch esesmanów wsypujących granulki gazu do komór, w których stłoczeni i eksterminowani są Żydzi. Czas historyczny jest rozpoznawalny, sformułowana jest także polityczna ocena Zagłady. Wyczytamy w tym lamencie, iż mord na na-

38 Tamże, s. 38.

39 D. Roskies, Wartime Victim Writing in Eastern Europe, w: Literature of the Holocaust, red. A. Rosen, Cambridge University Press, Cambridge 2013, s. 15-32. 
rodzie żydowskim dokonany został przy współudziale obcych narodów, którym płacono nagrody za współudział. Mordercy są jednoznacznie nazwani. To barbarzyński, chociaż o wysokiej kulturze, naród niemiecki. Na ten plan czytelnego konkretu, rozpoznawalnego zwłaszcza w kontekście poprzednich fragmentów dziennika, nałożony jest plan metafizyczny. Bóg niemiecki okazał się silniejszy od Boga Żydów, jako biblijnemu Molochowi składana mu jest ofiara z mężczyzn, kobiet i dzieci. Gradowski wielokrotnie pisze o cierpieniu niewinnych niczemu dzieci, co jest utajoną polemiką z odczytaniem Zagłady jako kary za grzechy narodu. W innym fragmencie kreśli obraz diabła przechadzającego się po ziemi, on jest prawdziwym władcą współczesnego kronikarzowi świata.

Noc księżycowa możemy przeczytać bez odwoływania się do żydowskiej tradycji. W takiej lekturze dostrzeżemy elementy historycznego świadectwa, bezmiar rozpaczy mówiącego podmiotu, patos lamentu, dramatyczne oskarżenie Boga, świata, ludzkości. Pominięty zostanie jednak religijny wymiar duchowego formatu autora-świadka Zagłady. Dlatego istotny jest namysł nad niezwykle złożoną symboliką księżyca, do jakiej odwołuje się więzień Sonderkommando. Adresatem rozpaczy jest Bóg, mimo iż autor zwraca się wprost do ciała niebieskiego. Piotr M.A. Cywiński uważa, że tym sposobem Załmen Gradowski, który był człowiekiem religijnym, unika bluźnierstwa ${ }^{40}$. Podobnie księżyc, jako substytut Boga, odczytuje Nathan Cohen, uważa jednak za zasadną również lekturę, w której adresatem wypowiedzi jest satelita Ziemi, rozświetlający zimnym blaskiem krajobraz śmierci. Gradowski pisze:

Czuję się lepiej w ciemności, pod panowaniem smutnej martwej nocy. Ta noc harmonizuje z uczuciami mojego serca i męką mojej duszy. Ciemna noc jest moim przyjacielem, płacz i zgrzyt to mój śpiew, ogień ofiar to moje światło, atmosfera śmierci to mój aromat, piekło jest moim domem. Dlaczego i po co przychodzisz tutaj obcy, okrutny księżycu i przeszkadzasz ludziom w nieświadomości nieszczęścia?41

Sensy ewokowane w Nocy księżycowej staną się bardziej czytelne, gdy odwołamy się do żydowskiego folkloru. Wydaje się, iż Gradowski nawiązuje w tej lirycznej partii notatek do uroczystości Błogostawieństwa księżyca, Kid(d)usz (ha-)lewana ${ }^{42}$. Zazwyczaj jest to wspólna modlitwa odmawiana od trzeciej do

\footnotetext{
${ }^{40}$ P.M.A. Cywiński, Zagłada..., s. 75, przypis 67.

${ }^{41}$ Z. Gradowski, Noc księżycowa, s. 72.

${ }^{42}$ Podstawą mojej interpretacji tekstu Gradowskiego są informacje zawarte w artykule Davida Zaklinowskiego, Sanctification of the Moon. Kiddush Levanah, the blessing on the moon [online], chabad.org/library/article_cdo/aid/1904288/jewish/Sanctification-of-the-Moon.htm [dostęp 15.05.2016]. Fragment, w którym omawiam uroczystość Błogosławieństwa księżyca, zamieściłem wcześniej w referacie Sacrum i profanum w relacji więźniów Sonderkommando, wygłoszonym podczas konferencji Humanistyczny wiatr od morza. Między sacrum a profanum. Literatura-ję$z y k$ - kultura - dydaktyka, Ustka 2-4 czerwca 2016. Tekst ten został opublikowany pod błędnym
} 
piętnastej nocy po ukazania się księżyca, czyli do jego pełni. Uczestnicy uroczystości gromadzą się pod gołym niebem. Modlitwie towarzyszy recytacja psalmów i fragmentów Talmudu. Błogosławieństwo nowego księżyca to pozdrowienie Boskiej obecności. Kidusz lewana jest obrzędem radosnym. W kolejności recytowane są fragmenty Psalmów: 148 , 121, 150, 67 oraz Pieśni nad Pieśniami. Wyrażają one chwałę Boga sławionego przez niebiosa, słońce, księżyc, człowieka, pieśniarzy, kapłanów. Obrzęd jest uroczystością pochwalną Boga wszechmocnego, sprawiedliwego sądzącego narody. Psalm 67 zawiera prośbę o błogosławieństwo i wyraża bojaźń przed Bożą wszechmocą. W czasie uroczystości Królestwo Izraela zostaje porównane do odnawiającego się księżyca. Chociaż utraciło blask, to wróci w chwale w czasach mesjańskich, jak księżyc w pełni. Uroczystość kończy (jeśli zbierze się podczas niej dziesięciu mężczyzn - stąd jest ona obchodzona gromadnie, po sąsiedzku) recytacja kadiszu, a potem następują wspólne tańce właściwe ślubnym uroczystościom. Podczas celebracji ważny jest moment oddalenia wrogów (są oni tak daleko jak księżyc) i zinterpretowania pojawienia się księżyca jako znaku dobrej wróżby dla wygłaszających błogosławieństwo i dla całego narodu żydowskiego.

Noc księżycowa Załmena Gradowskiego jest swoistym zaprzeczeniem Kidusz lewana. To tekst pełen oskarżeń, negujący moc księżyca. Autor przemawia jak psalmista z mroków nieszczęścia: „Widzisz spoglądam ku tobie z mojego zakratowanego piekła. Znajduję się w sercu piekła, w którym ginie mój naród”³, przypomina Hioba. Przede wszystkim jest jednakże samotny, jego dzieci i żona zostały spalone w krematorium. Pojawienie się księżyca nie wyraża nadziei na odrodzenie potęgi Izraela. Naród żydowski ginie otruty gazem, umiera z głodu i pragnienia podczas okrutnych transportów. To samotny głos, jakże daleki od idei wspólnej celebracji święta. W tekście wyraźnie zaznaczona jest cezura między radością dawnej rodzinnej sąsiedzkiej uroczystości, a teraźniejszą pustką pod zimnym, drwiącym i okrutnym blaskiem Księżyca. Autor w serii kilkunastu retorycznych pytań oskarża Księżyc o egoizm, sadyzm, brak współczucia. Jego światło naigrywa się z męczeństwa Żydów. Pyta, dlaczego ,ukazujesz się tutaj, gdzie powietrze napełnione jest śmiercią i zagładą"44, dlaczego ukazujesz się tutaj, gdzie „wyschnięte cienie” patrzą nie na twoje światło, lecz „ogień, który wydobywa się z wysokich kominów ku niebu”" ${ }^{\text {. }}$. „Dlaczego świecisz jeszcze dzisiaj z taką wspaniałością i czarem" ${ }^{\prime 46}$. Niejednokrotnie wydaje się, iż autor zwraca się wprost do Boga: „Nic nie jest wart świat, ludzkość nie jest warta, by korzystać

tytułem Shaul Chasan, więzień Sonderkommando Auschwitz w: Między sacrum a profanum. Rozważania i dylematy, pod red. G. Różańskiej, Dante, Kraków 2017, s. 169-178.

${ }^{43}$ Z. Gradowski, Noc księżycowa, s. 78.

44 Tamże, s. 73.

45 Tamże.

${ }^{46}$ Tamże, s. 77. 
z twojego światła!'^77. W innym miejscu przedstawia krematorium jako ołtarz ofiarny, na którym kulturalny, silny i potężny naród „diabelskiemu bogu” oddaje hołd, mordując , jego braci i siostry z całego świata" ${ }^{48}$, paląc „,niewinne niczemu dzieci’"49. Tekst Nocy księżycowej kończy przekonanie o całkowitym unicestwieniu ludu żydowskiego. Zwraca się więc autor do księżyca, by skierował jeden jedyny promień na ofiary: „Tylko ty jesteś świadkiem nieszczęścia, zagłady mojego narodu, mojego świata" ${ }^{50}$.

\section{V.}

Zapisy Gradowskiego są głosem z epicentrum Zagłady, pochodzą z progu komory gazowej. Od pozostałych pięciu świadectw członków Sonderkommanda, odnalezionych po wojnie w pobliżu ruin krematoriów różni je literacka wartość, którą dostrzegł Wygodzki. Chociaż zapis ten dotarł do nas we fragmentach, to do pewnego stopnia możemy odtworzyć jego walor kompozycyjny, narracyjny, wskazać „naddane” uporządkowanie języka przekazu. Gradowski jest twórcą świadomym, na pewno kształt literacki notatek nie wynika jedynie z odtworzenia jego indywidualnego języka - na taką możliwość wskazywał w przywoływanym artykule Nathan Cohen.

Notatki Gradowskiego zmuszają do postawienia zasadniczych pytań. Czy rzeczywiście ich literackość przesłania doświadczenie Auschwitz? ${ }^{51}$ Czy empatia czytelnicza osiągnięta przy pomocy środków retorycznych, technik narracyjnych, metaforyki i emocjonalnego języka oddziela nas, czy przybliża do zrozumienia tego granicznego doświadczenia europejskiej cywilizacji? ${ }^{52} \mathrm{Czy}$ świadkiem całkowitym Zagłady jest jedynie muzułman Primo Leviego i Giorgio Agambena? Ten może nim być przecież jedynie jako milcząca figura symboliczna. To przecież zapisy więźniów Sonderkommanda, w tym omawiany tu dziennik/pamiętnik Gradowskiego precyzyjnie ukazuje techniczny, logistyczny

47 Tamże.

48 Tamże, s. 79.

49 Tamże, s. 81

50 Tamże, s. 82.

${ }^{51}$ To teza sformułowana w słynnym pytaniu Theodora Adorna o możliwość istnienia poezji po Auschwitz. Radykalne stanowisko zajmuje tu znakomity badacz Holokaustu Berel Lang, który opowiada się za językiem faktów, zauważając, iż język poetycki ,wchodzi” między odbiorcę a Holokaust. Zob. B. Lang, Przedstawienie zła: etyczna treść a literacka forma, tłum. A. Ziębińska-Witek, „Literatura na Świecie” 2004, nr 1-2, s. 15-63.

52 Marta Zawodny w artykule Świadectwo śmierci Innego w zapiskach Zatmena Gradowskiego („Rocznik Antropologii Historii” 2013, nr 1, s. 249) twierdzi, iż dystans narratora/obserwatora, będący świadomym zabiegiem literackim, ,pogłębia dystans czytelnika”. 
i psychologiczny wymiar ludobójstwa dokonującego się w komorach gazowych. Teksty te pod znakiem zapytania stawiają też błyskotliwą i popularną formułę Dori Lauba o Zagładzie jako wydarzeniu bez świadków. Przypomnijmy, iż Laub jest psychoterapeutą i jego koncept zrodził się w wyniku rozmów z ocalonymi z Zagłady, których psychika stosowała mechanizmy wyparcia tragicznych doświadczeń w ich biografii ${ }^{53}$. I wreszcie, co decyduje o wadze świadectwa? Wydaje się, że przede wszystkim format duchowy świadka, jego usytuowanie w świecie zbrodni i sama chęć złożenia świadectwa. W przypadku omawianego tekstu jego literackie ukształtowanie nie tylko wywołuje empatię czytelnika, ale podkreśla jego autentyczność ${ }^{54}$. Przy czym piszę o empatii, nie o identyfikacji czytelnika $\mathrm{z}$ autorem. Wydaje się, że Robert Eaglestone słusznie uznał niemożność zaistnienia tej ostatniej za cechę wyróżniającą świadectwa ofiar Zagłady ${ }^{55}$. Załmen Gradowski jest z pewnością jednym z najważniejszych świadków Holokaustu, jego relacja pisana $\mathrm{w}$ niektórych fragmentach jako pamiętnik, co prawda $\mathrm{z}$ bardzo krótkiego dystansu czasu, bynajmniej nie przekreśla poznawczych walorów narracji ${ }^{56}$.

Teksty te wykopywane z ludzkich prochów, ukryte w słoikach i menażkach, same jako fakt fizyczny stanowią rodzaj świeckich relikwii. Pisząc o literackim ukształtowaniu notatek Gradowskiego, nie do końca przezwyciężyłem odczucie dokonywania profanacji. Dzisiaj jest być może ono mniej intensywne niż gdybym ich literackość rozważał blisko dwadzieścia lat temu poruszony artykułem Wygodzkiego w „Nowinach-Kurierze" ${ }^{57}$. Zapewne dlatego, że o Zagładzie już od wielu lat piszą nie tylko ocaleńcy, a bogata literatura postpamięci oswoiła nas z narracjami figuratywnymi. Nie umniejszając znaczenia tych ostatnich, tym

${ }^{53}$ D. Laub, Zdarzenie bez świadka: prawda, świadectwo, oraz ocalenie, tłum. Tomasz Łysak, „Teksty Drugie” 2007, nr 5, s. 118-130. Fragment pochodzi z książki: S. Felman, D. Laub, Testimony, Crises of Witnessing in Literature, Psychoanalysis, and History, Routledge, New York-London 1992.

54 Podobnie o znaczeniu literackiego nacechowania tekstów świadectw pisze Maria Delaperrière, Świadectwo jako problem literacki, „Teksty Drugie” 2006, nr 3, s. 59-70.

${ }^{55}$ R. Eaglestone, The Holocaust and the Postmodern, Oxford University Press, Oxford 2004, s. 38.

${ }^{56}$ Tezę o nieprzystawalności form narracyjnych do doświadczenia Zagłady formułuje Barbara Foley, Fact, Fiction, Fascicm. Testimony and Mimezis in Holocaust Narratives, „Comparative Literature" 1982, nr 34, s. 330-360.

${ }^{57}$ Dokładnie dwadzieścia lat temu zmagał się z podobnym dylematem Jacek Leociak w kanonicznej w polskim naukowym dyskursie o Holokauście książce Tekst wobec Zagłady. O relacjach z getta warszawskiego, wydanej po raz pierwszy w 1997 roku. Odsyłam do stron 33-37 wydania toruńskiego z 2016 roku. Autor zajmuje stanowisko, które nazywa umiarkowanym. Wyraża się ono w badaniu dyskursu, przy zwróceniu jednakże uwagi na treść przekazu, obraz zawartej w nim rzeczywistości. W namyśle nad ukształtowaniem tekstu dostrzega on możliwość dotarcia do autora świadectwa jako człowieka. Leociak pisze: „Czytamy tekst, aby w ostatecznym rachunku dotrzeć do człowieka i zrozumieć go" (s. 36). 
bardziej powinniśmy wracać do bezpośrednich świadków i świadectw - w tym przypadku świadectwa powstałego w Auschwitz-Birkenau, miejscu, którego nazwa stała się synonimem Holokaustu.

\section{Bibliografia}

Cohen Nathan, „Diaries” of the Sonderkommando, w: Anatomy of the Auschwitz Death Camp, red. Yisrael Gutman i Michael Berenbaum, Indiana University Press, Bloomington 1998, s. 522-534.

Czech Danuta, Kalendarz wydarzeń w KL Auschwitz, Wydawnictwo Państwowego Muzeum w Oświęcimiu-Brzezince, Oświęcim 1992.

Delaperrière Maria, Świadectwo jako problem literacki, „Teksty Drugie” 2006, nr 3, s. 59-70.

Eaglestone Robert, The Holocaust and the Postmodern, Oxford University Press, Oxford 2004.

Foley Barbara, Fact, Fiction, Fascicm. Testimony and Mimezis in Holocaust Narratives, „Comparative Literature" 1982, nr 34, s. 330-360.

Friedländer Saul, Czas eksterminacji. Nazistowskie Niemcy i Żydzi 1939-1945, przekł. Sławomir Kupisz, Anna Maria Nowak, Krzysztof Masłowski, Prószyński Media, Warszawa 2010.

Gradowski Załmen, [List], [Dziennik], przekł. Bernard Mark, popr. i uzup. Roman Pytel, „Zeszyty Oświęcimskie" 1972, numer specjalny (II): Wśród koszmarnej zbrodni. Rękopisy członków Sonderkommando, s. 131-162.

Gradowski Załmen, Noc księżycowa, przekł. Elżbieta Golińska, w: Cywiński Piotr M.A., Zagłada w pamięci więźniów Sonderkommando, Państwowe Muzeum Auschwitz-Birkenau, Oświęcim 2015, s. 69-82.

Gradowski Załmen, Wolny człowieku wiedz, że to jest ogień z piekła..., „Pro memoria” 2006, nr 25, s. 35-44.

Greif Gideon, ,...płakaliśmy bez łez...”. Relacje bytych więźniów żydowskiego Sonderkommando z Auschwitz, tłum. Jan Kapłon, konsultacja nauk. Franciszek Piper, Piotr Setkiewicz, Żydowski Instytut Historyczny, Państwowe Muzeum Auschwitz-Birkenau, Warszawa-Oświęcim 2001.

Kielar Wiesław, Anus mundi, przedm. Mieczysław Kieta, Atut, Wrocław 2004.

Lang Berel, Przedstawienie zła: etyczna tressć a literacka forma, tłum. Anna Ziębińska-Witek, „Literatura na Świecie” 2004, nr 1-2, s. 15-63.

Laub Dori, Zdarzenie bez świadka: prawda, świadectwo, oraz ocalenie, tłum. Tomasz Łysak, „Teksty Drugie” 2007, nr 5, s. 118-130.

Leociak Jacek, Tekst wobec Zagłady. O relacjach z getta warszawskiego, Wydawnictwo Naukowe Uniwersytetu Mikołaja Kopernika, Torun 2016.

Levi Primo, Pogrążeni i ocaleni, przekł. Stanisław Kasprzysiak, Wydawnictwo Literackie, Kraków 2007.

Mark Bernard, O rękopisie Załmena Gradowskiego, „Zeszyty Oświęcimskie” 1972, nr specjalny (II): Wśród koszmarnej zbrodni. Rękopisy członków Sonderkommando, s. 127-130.

Roskies David, Wartime Victim Writing in Eastern Europe, w: Literature of the Holocaust, red. Alan Rosen, Cambridge University Press, Cambridge 2013, s. 15-32.

Szwarc Zając Anna, Willy, przyjaciel prawdziwy czy wymyślony? Rozważania nad polskim i włoskim tłumaczeniem książi ,, Szukajcie w popiołach”, „Zagłada Żydów. Studia i Materiały”, t. 8 (2012), s. $403-418$. 
Wygodzki Stanisław, W sercu piekta, „Nowiny-Kurier” 1977, nr 157, s. 8.

Zaklinowski David, Sanctification of the Moon. Kiddush Levanah, the blessing on the moon [online], chabad.org/library/article_cdo/aid/1904288/jewish/Sanctification-of-the-Moon.htm [dostęp 15.05.2016].

Zawodny Marta, Świadectwo śmierci Innego w zapiskach Zalmena Gradowskiego, „Rocznik Antropologii Historii” 2013, nr 1, s. 241-250.

\section{Kazimierz Adamczyk}

\section{Report and Lament - Zalmen Gradowski’s Notes from Auschwitz}

\section{Summary}

Notes of Załmen Gradowski, one of the leaders of the Sonderkommando revolt in Auschwitz-Birkenau, is one of the most important documents of the Holocaust produced by his victims during the crime and at its epicenter. Their fragments were published in Poland and Israel. Gradowski was a religious Jew from Grodno, he prayed daily in the camp and wrote down transport information. His family: mother, wife and children, immediately after arriving in Auschwitz, were murdered in gas chambers. The author analyzes the literary value of this extraordinary document, which consists of narrative diary entries and imaginative lyrical inscriptions, rooted in the Jewish tradition of conversation with God. So we read the records of the nature of the report and lament. This unique record - given its place of origin and literary values - a testimony of the crimes committed against and suffering of the victims of the Holocaust once again asks us about the inexpressibility of the Holocaust.

Keywords: Załmen Gradowski; Holocaust; Auschwitz-Birkenau; Jews; Sonderkommando; gas-chamber, testimony; literariness 